\title{
Survey of Finance Companies, 2000
}

Karen E. Dynan, Kathleen W. Johnson, and Samuel M. Slowinski, of the Board's Division of Research and Statistics, prepared this article with assistance from Greg D. Grothe and Hank Leddon.

Finance companies are important providers of credit to households and businesses. For households, they originate loans and leases to finance the purchase of consumer goods such as automobiles, furniture, and household appliances; they also extend personal cash loans and loans secured by junior liens on real estate, such as home equity loans. For businesses, they supply short- and intermediate-term credit (including leases) for such purposes as the purchase of equipment and motor vehicles and the financing of inventories. ${ }^{1}$

With roughly $\$ 1$ trillion in financial assets as of mid-2000, the finance company sector occupies an intermediate position among the sectors that typically lend to households and businesses: In terms of assets, it is more than twice as large as the credit union sector, about the same size as the thrift sector, but only about one-fifth as large as the commercial banking sector. The approximately 1,000 companies that make up the sector (down from about 1,200 in 1996) range in size from very small to very large and include the "captive" subsidiary finance companies of motor vehicle manufacturers. The companies tend to be diversified, with more than 90 percent of the sector's assets as of mid- 2000 held by companies that did not concentrate in any one type of receivable. The larger firms are more likely to be diversified; of the small firms that specialize, most focus on short- and intermediate-term business receivables. The sector is quite concentrated, and has been for some time, with the twenty largest companies accounting for more than two-thirds of total receivables (see box "Industry Concentration").

The Federal Reserve System has surveyed the assets and liabilities of finance companies at roughly five-year intervals since 1955. The surveys provide

1. For this article, finance companies are defined as financial institutions-other than commercial banks, credit unions, savings and loan associations, cooperative banks, or savings banks-the majority of whose assets are in one or more of the types of accounts receivable described above. (An "account receivable," sometimes referred to as simply a receivable, is a balance due from a debtor on a current account.) benchmarks for the System's monthly report on the outstanding accounts receivable of finance companies and provide a comprehensive update on these companies' sources of funds. This information in turn becomes an important input to the estimates of total consumer credit and the U.S. flow of funds accounts produced at the Federal Reserve Board. Summarized in this article are the results of the most recent survey, which collected finance company balance sheet information as of June 30, 2000. (Details on sampling procedures are given in appendix $A$, and complete balance sheet data are provided in table B.1.)

\section{FINANCE COMPANY RECEIVABLES}

The total value of receivables owned or securitized by finance companies increased nearly 50 percent between 1996 and 2000, or approximately 11 percent a year on average (table 1). ${ }^{2}$ The gain occurred against a backdrop of brisk economic expansion, with nominal gross domestic product increasing at an average annual rate of about 6 percent over the period. Business lending remained the largest major line of activity, accounting for just under half of all receivables. There was apparently some shift between the other two major lines of activity, however. The share of total receivables accounted for by consumer lending and leasing declined 2 percentage points (to 39 percent); that decline was matched by a comparable rise in the share accounted for by real estate loans (to 17 percent). With most real estate receivables at finance companies being home equity loans, this shift may indicate that households have been substituting lower-cost, collateralized home equity loans for high-cost, uncollateralized consumer loans as a source of credit.

Finance companies sometimes securitize their loans by pooling them and selling them to a bankruptcy-remote entity, which then sells securities backed by the revenue stream generated by the loans. ${ }^{3}$ A securitized loan is removed from the

2. Unless otherwise noted, all statistics cited are as of June 30 of the year indicated.

3. A "bankruptcy-remote" entity is one whose assets will not enter receivership if the originating finance company declares bankruptcy. 


\section{Industry Concentration}

Overall, concentration in the finance company industry was about unchanged between the 1996 and 2000 surveys, marking a break in the steady trend toward consolidation seen in earlier surveys. Total receivables at the twenty largest firms (based on total net assets) represented 69 percent of total industry receivables in mid2000, compared with 70 percent in mid-1996 (table).

Owned business receivables became markedly less concentrated, with the twenty largest firms accounting for 11 percentage points less of all such receivables in 2000 than they had four years earlier. The underlying data suggest that the shift in owned business receivables toward smaller firms was attributable primarily to a sizable decline in the concentration of business (non-motor vehicle) equipment receivables. As smaller companies are less likely than large ones to identify themselves as diversified, the decline in the concentration of owned business equipment receivables may suggest that specialization has become an increasingly efficient way of providing funds for this type of investment

The other major components of finance company receivables became more concentrated between 1996 and 2000. The shares of owned consumer and real estate receivables accounted for by the twenty largest firms moved up 3 percentage points and 4 percentage points, respectively. The concentration of securitized receivables rose sharply, with the share of the twenty largest firms 12 percentage points higher in 2000 than in 1996. The concentration of securitized receivables also rose impressively between the 1990 and 1996 surveys. The upward trend suggests that the relative attractiveness of the products of the larger securitization programs has risen over time, possibly because investors have increasingly associated these more-established programs with lower risk.

Total receivables at finance companies, by category, June 30, 1996 and 2000

Billions of dollars except as noted

\begin{tabular}{|c|c|c|c|c|c|c|}
\hline \multirow{3}{*}{ Category } & \multirow{2}{*}{\multicolumn{2}{|c|}{$\begin{array}{l}\text { All fiance } \\
\text { companitus }\end{array}$}} & \multicolumn{4}{|c|}{ Twenty lirgest finince companics' } \\
\hline & & & \multicolumn{2}{|c|}{ Amount } & \multicolumn{2}{|c|}{$\begin{array}{l}\text { Share al all } \\
\text { finance compriny } \\
\text { recei } \\
\text { (periblent) }\end{array}$} \\
\hline & 1996 & 2000 & 1996 & 2000 & 1996 & 2000 \\
\hline Total & 749.1 & $1,119.6$ & 524.9 & 770.3 & 70.1 & 68.8 \\
\hline $\begin{array}{c}\text { Owned ...... } \\
\text { Business } \\
\text { Consumer } \\
\text { Real estate } \\
\text { Securitized }\end{array}$ & $\begin{array}{r}626.7 \\
305.7 \\
240.6 \\
80.4 \\
122.4\end{array}$ & $\begin{array}{l}921.5 \\
441.9 \\
321.8 \\
157.7 \\
198.1\end{array}$ & $\begin{array}{r}459.1 \\
194.5 \\
203.5 \\
61.1 \\
65.8\end{array}$ & $\begin{array}{l}639.9 \\
232.0 \\
281.8 \\
126.1 \\
130.4\end{array}$ & $\begin{array}{l}73.3 \\
63.6 \\
84.6 \\
76.0 \\
53.8\end{array}$ & $\begin{array}{l}69.4 \\
52.5 \\
87.6 \\
79.9 \\
65.8\end{array}$ \\
\hline $\begin{array}{l}\text { Мемо } \\
\text { Total net assets }\end{array}$ & 815.4 & $1,259.0$ & 615.9 & 962.5 & 75.5 & 76.4 \\
\hline
\end{tabular}

1. Total receivables at finance companies, by category, June 30, 1996 and 2000

\begin{tabular}{|c|c|c|c|c|c|c|}
\hline \multirow{2}{*}{ Category } & \multicolumn{2}{|c|}{$\begin{array}{l}\text { Amsunt } \\
\text { (bill ins } \\
\text { of dollars) }\end{array}$} & \multicolumn{2}{|c|}{$\begin{array}{l}\text { Growth; } \\
1996 \mathrm{t}, 20 \mathrm{iu} \\
\text { (per:ent) }\end{array}$} & \multicolumn{2}{|c|}{ 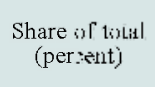 } \\
\hline & 1996 & 2000 & $\begin{array}{l}\text { Cumu- } \\
\text { lative }\end{array}$ & $\begin{array}{c}\text { Average } \\
\text { annual }\end{array}$ & 1996 & 2000 \\
\hline Total & 749.1 & $1,119.6$ & 49.5 & 10.6 & 100.0 & 100.0 \\
\hline Owned & 626.7 & 921.5 & 47.0 & 10.1 & 83.7 & 82.3 \\
\hline Securitized & 122.4 & 198.1 & 61.9 & 12.8 & 16.3 & 17.7 \\
\hline Business & 341.3 & 502.5 & 47.2 & 10.2 & 45.6 & 44.9 \\
\hline Owned & 305.7 & 441.9 & 44.5 & 9.6 & 40.8 & 39.5 \\
\hline Securitized & 35.6 & 60.6 & 70.2 & 14.2 & 4.8 & 5.4 \\
\hline Consumer & 303.9 & 431.8 & 42.1 & 9.2 & 40.6 & 38.6 \\
\hline Owned & 240.6 & 321.8 & 33.8 & 7.5 & 32.1 & 28.7 \\
\hline Securitized & 63.3 & 110.0 & 73.6 & 14.8 & 8.5 & 9.8 \\
\hline Real estate & 103.8 & 185.3 & 78.5 & 15.6 & 13.9 & 16.6 \\
\hline Owned & 80.4 & 157.7 & 96.3 & 18.4 & 10.7 & 14.1 \\
\hline Securitized & 23.5 & 27.5 & 17.4 & 4.1 & 3.1 & 2.5 \\
\hline
\end{tabular}

Note. In this and subsequent tables, details may not sum to totals, and calculations may not yield the percentages shown, because of rounding.

finance company's balance sheet, although the company typically continues to collect the service payment and would bear the cost of a default. ${ }^{4}$ After rising rapidly in the early $1990 \mathrm{~s}$, when securitization was a relatively new practice, the proportion of finance company loans that was securitized increased only moderately in the late $1990 \mathrm{~s}$, from 16 percent in 1996 to 18 percent in 2000.

\section{Business Receivables}

Finance companies owned or had securitized $\$ 503$ billion in business receivables as of June 30, 2000 , accounting for roughly 8 percent of total nonfinancial business credit and close to 22 percent of short- and intermediate-term business credit (table 2). Between 1996 and 2000, finance company business receivables increased at an average annual rate of 10 percent, approximately matching the rates of growth of alternative sources of short-term business finance, such as bank loans, and longer-term instruments, such as corporate bonds and mortgages. As a result, finance companies maintained their share of the market for nonfinancial business credit over the intrasurvey period.

Finance companies appear to be an important source of funds for small businesses-firms with

4. In most securitization deals, finance companies retain the "excess spread" - the difference between the yield on the loans and such expenses as the investor coupon, servicing fee, and losses associated with defaults. As a result, they typically retain the credit risk of securitized portfolios. 
2. Credit to nonfinancial businesses from all domestic sources, by instrument, June 30,1996 and 2000

\begin{tabular}{|c|c|c|c|c|c|c|c|c|}
\hline \multirow{2}{*}{ Instrument } & \multicolumn{2}{|c|}{$\begin{array}{l}\text { Am sum1 } \\
\text { (billions of dollars) }\end{array}$} & \multicolumn{2}{|c|}{$\begin{array}{c}\text { Growth, } 1936 \text { is } 2000 i] \\
\text { (per:ent) }\end{array}$} & \multicolumn{2}{|c|}{$\begin{array}{c}\text { Share of untisgery } \\
\text { (per:ent) }\end{array}$} & \multicolumn{2}{|c|}{$\begin{array}{l}\text { Share of totiil } \\
\text { (percent) }\end{array}$} \\
\hline & 1996 & 2000 & Cumulative & $\begin{array}{l}\text { Average } \\
\text { annual }\end{array}$ & 1996 & 2000 & 1996 & 2000 \\
\hline All credit market instruments & $4,276.2$ & $6,337.4$ & 48.2 & 10.3 & 100.0 & 100.0 & 100.0 & 100.0 \\
\hline Short- and intermediate-term instruments & $1,598.8$ & $2,333.2$ & 45.9 & 9.9 & 100.0 & 100.0 & 37.4 & 36.8 \\
\hline Bank loans n.e.c. .................. & 835.0 & $1,235.5$ & 48.0 & 10.3 & 52.2 & 53.0 & 19.5 & 19.5 \\
\hline Other loans and advances & 582.0 & 800.8 & 37.6 & 8.3 & 36.4 & 34.3 & 13.6 & 12.6 \\
\hline Finance company receivables & 341.3 & 502.5 & 47.2 & 10.2 & 21.3 & 21.5 & 8.0 & 7.9 \\
\hline Commercial paper $\quad . . . \ldots \ldots .$. & 181.7 & 296.8 & 63.3 & 13.1 & 11.4 & 12.7 & 4.2 & 4.7 \\
\hline Long-term instruments & $2,677.4$ & $4,004.3$ & 49.6 & 10.6 & 100.0 & 100.0 & 62.6 & 63.2 \\
\hline Corporate bonds & $1,405.0$ & $2,144.5$ & 52.6 & 11.2 & 52.5 & 53.6 & 32.9 & 33.8 \\
\hline Mortgages & $1,135.3$ & $1,706.4$ & 50.3 & 10.7 & 42.4 & 42.6 & 26.6 & 26.9 \\
\hline Municipal securities & 137.1 & 153.4 & 11.9 & 2.8 & 5.1 & 3.8 & 3.2 & 2.4 \\
\hline
\end{tabular}

n.e.c. Not elsewhere classitied.

fewer than 500 employees. In 1998, about 14 percent of all small businesses, and roughly 30 percent of small businesses with more than 100 employees or annual sales totaling more than $\$ 10$ million, used finance companies for loans, leases, and financial management. Small businesses used finance companies mainly for motor vehicle loans and capital leases, areas in which finance companies specialize. Small businesses were only slightly less likely to use a finance company than a commercial bank to finance their motor vehicle purchases and were equally likely to use a finance company or a commercial bank for their capital leases. ${ }^{5}$

Although the overall importance of finance companies in the business credit market apparently remained stable between 1996 and 2000, there were a few shifts in the composition of finance company business lending. These shifts included movements from owned toward securitized equipment loans, from business financing for investment in equipment and motor vehicles toward other types of business finance, and from loans to purchase business motor vehicles toward leases.

\section{Equipment Finance}

Loans and leases for business equipment (other than motor vehicles) accounted for close to 60 percent of total finance company business receivables in 2000 (table 3). Such funding typically supports business investment in such items as construction equipment, aircraft, and computers and other office machines.

5. Marianne P. Bitler, Alicia M. Robb, and John D. Wolken, "Financial Services Used by Small Businesses: Evidence from the 1998 Survey of Small Business Finances," Federal Reserve Bulletin, vol. 87 (April 2001), pp. 183-205.
Although the growth of equipment loans and leases tends to be correlated with the growth of business investment in equipment, finance company equipment loans and leases expanded at an average annual rate of 9 percent between 1996 and 2000, somewhat less than the 11 percent average annual increase in investment in business equipment and software (excluding motor vehicles) over the period. For comparison, commercial paper and commercial and industrial loans extended by commercial banksother sources of short- and intermediate-term business debt that may be used to finance equipment investment - rose at average annual rates of 13 percent and 12 percent, respectively, over the period.

Equipment leases, which account for the lion's share of equipment receivables at finance companies, increased at an average annual rate of about 9 percent between 1996 and 2000. ${ }^{\circ}$ Despite the considerable size of their equipment lease portfolios, finance companies as a whole generally keep these receivables on their balance sheets rather than securitize them. Indeed, only about 3 percent of equipment leases were in securitized pools in 2000. Nonetheless, some small finance companies securitize a large portion of their equipment lease portfolios.

Overall, equipment loans rose at an average annual rate of 8 percent between surveys. Although securitized equipment loans increased much faster (34 percent annually), they continue to account for only a small share of total equipment receivables-about 6 percent in 2000 .

6. Most equipment and business motor vehicle leases extended by finance companies are capital leases. Most capital leases are quite long relative to the useful life of the leased item, and although the finance company retains the title to the item during the leasing period, lease payments are generally applied toward its eventual purchase. In this way, leases are similar to equipment and business motor vehicle loans. 
3. Business receivables at finance companies, by category, June 30,1996 and 2000

\begin{tabular}{|c|c|c|c|c|c|c|c|c|}
\hline \multirow{2}{*}{ Category } & \multicolumn{2}{|c|}{$\begin{array}{c}\text { Am sunt } \\
\text { (billions ot dollars) }\end{array}$} & \multicolumn{2}{|c|}{$\begin{array}{c}\text { Growth, } 19 \times 6 \text { is } 2000 i] \\
\text { (perient) }\end{array}$} & \multicolumn{2}{|c|}{$\begin{array}{l}\text { Share of uilicysry } \\
\text { (per:ent) }\end{array}$} & \multicolumn{2}{|c|}{$\begin{array}{l}\text { Share of totiil } \\
\text { (percent) }\end{array}$} \\
\hline & 1996 & 2000 & Cumulative & $\begin{array}{l}\text { Average } \\
\text { annual }\end{array}$ & 1996 & 2000 & 1996 & 2000 \\
\hline Total & 341.3 & 502.5 & 47.2 & 10.2 & 100.0 & 100.0 & 100.0 & 100.0 \\
\hline Equipment & 205.0 & 289.9 & 41.4 & 9.1 & 100.0 & 100.0 & 60.1 & 57.7 \\
\hline Leases & 141.9 & 203.4 & 43.3 & 9.4 & 69.2 & 70.1 & 41.6 & 40.5 \\
\hline Owned & 137.9 & 196.9 & 42.8 & 9.3 & 67.3 & 67.9 & 40.4 & 39.2 \\
\hline Securitized & 4.1 & 6.4 & 58.0 & 12.1 & 2.0 & 2.2 & 1.2 & 1.3 \\
\hline Loans..... & 63.0 & 86.6 & 37.3 & 8.3 & 30.8 & 29.9 & 18.5 & 17.2 \\
\hline Owned & 58.2 & 70.7 & 21.6 & 5.0 & 28.4 & 24.4 & 17.0 & 14.1 \\
\hline Securitized & 4.9 & 15.8 & 225.0 & 34.3 & 2.4 & 5.5 & 1.4 & 3.1 \\
\hline Motor vehicle & 89.2 & 105.9 & 18.8 & 4.4 & 100.0 & 100.0 & 26.1 & 21.1 \\
\hline Wholesale loans & 54.5 & 65.0 & 19.2 & 4.5 & 61.1 & 61.3 & 16.0 & 12.9 \\
\hline Owned & 32.3 & 38.5 & 19.3 & 4.5 & 36.2 & 36.4 & 9.5 & 7.7 \\
\hline Securitized & 22.2 & 26.4 & 19.0 & 4.5 & 24.9 & 25.0 & 6.5 & 5.3 \\
\hline Retall & 34.7 & 41.0 & 18.1 & 4.3 & 38.9 & 38.7 & 10.2 & 8.2 \\
\hline Loans & 26.9 & 22.8 & -15.2 & -4.0 & 30.2 & 21.5 & 7.9 & 4.5 \\
\hline Owned & 25.0 & 19.9 & -20.4 & -5.5 & 28.1 & 18.8 & 7.3 & 4.0 \\
\hline Securitized & 1.9 & 2.9 & 53.8 & 11.4 & 2.1 & 2.7 & 6 & 6 \\
\hline Leases $\ldots . .$. & 7.8 & 18.2 & 133.7 & 23.6 & 8.7 & 17.1 & 2.3 & 3.6 \\
\hline Owned & 7.8 & 15.8 & 103.1 & 19.4 & 8.7 & 14.9 & 2.3 & 3.1 \\
\hline Securitized & $\approx$ & 2.4 & . & $\ldots$ & $\approx$ & 2.2 & $*$ & .5 \\
\hline Other & 47.1 & 106.6 & 126.4 & 22.7 & 100.0 & 100.0 & 13.8 & 21.2 \\
\hline Owned & 44.6 & 100.0 & 124.2 & 22.4 & 94.7 & 93.8 & 13.1 & 19.9 \\
\hline Securitized & 2.5 & 6.6 & 164.9 & 27.6 & 5.3 & 6.2 & .7 & 1.3 \\
\hline
\end{tabular}

\section{Wholesale Motor Vehicle Finance}

Wholesale motor vehicle loans, which are supplied mainly by the captive subsidiary finance companies of motor vehicle manufacturers, are typically used by automobile dealers to finance their inventories (an activity known as floor-planning). Receivables at finance companies from this activity increased roughly 5 percent a year between surveys, to $\$ 65$ billion in 2000. As a proportion of total business receivables, however, wholesale motor vehicle loans fell from 16 percent to 13 percent. About 40 percent of wholesale automobile loans were securitized, almost exclusively by the captive financing arms of the Big Three automakers (Chrysler Financial Corporation, Ford Motor Credit, and General Motors Acceptance Corporation).

The growth between 1996 and 2000 of wholesale motor vehicle loans extended by finance companies tracked the growth of inventories at automobile dealers quite closely (chart 1). The rates of growth remained stable until mid-1998, when automobile sales surged. At that time, dealers increased their inventories sharply in order to keep their days' supply of vehicles roughly constant, and they stepped up their borrowing to finance the increase.

\section{Business Retail Motor Vehicle Finance}

Finance companies also provide credit for the retail sale to businesses of passenger cars and commercial vehicles such as trucks, buses, taxicabs, and truck trailers. Between 1996 and 2000, retail motor vehicle receivables at finance companies increased an average of 4 percent annually, generally mirroring the expansion of business investment in automobiles and trucks. There has been a clear trend in business retail motor vehicle financing toward leasing. The business retail motor vehicle lease portfolios of finance companies expanded an average of almost 24 percent annually between surveys, and in 2000 leases accounted for just under half of all business retail motor vehicle financing by finance companies. In contrast, finance companies' retail motor vehicle loan portfolios declined an average of 4 percent a year between surveys.

1. Wholesale motor vehicle lending by finance companies, 1996-2000

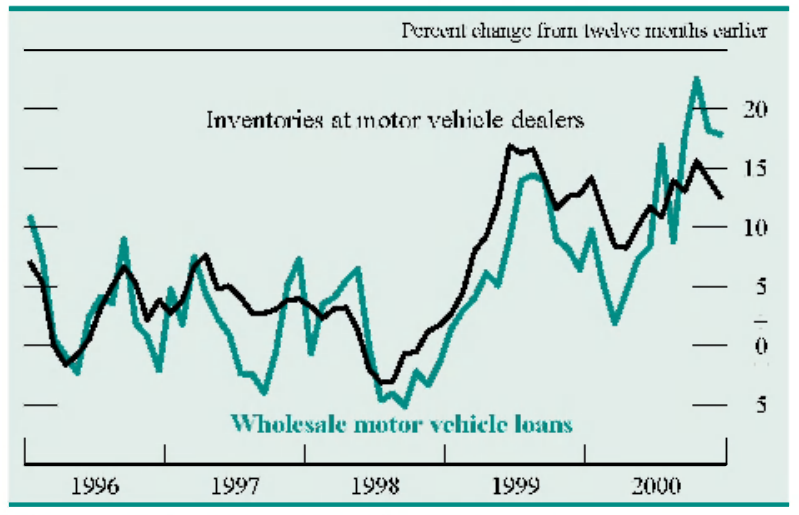

NoTE. The data on inventories are from the U.S. Census Bureau. 


\section{Other Business Receivables}

"Other business receivables" include commercial accounts receivable, factored commercial accounts, floor-plan loans to dealers in non-automotive goods, and small cash loans to businesses and farms. ${ }^{7}$ Financing in this category rose rapidly between 1996 and 2000 , increasing from about 14 percent of total business receivables at finance companies to roughly 21 percent. However, little quantitative information is available to determine which types of business receivables accounted for the gain.

\section{Consumer Receivables}

The consumer segment of finance company activity expanded at a robust 9 percent annual pace between surveys, with receivables (including securitized loans and leases) reaching $\$ 432$ billion by mid-2000 (table 4). At that time, finance company consumer receivables excluding motor vehicle leases accounted for just over 20 percent of total consumer debt.

Finance company consumer receivables increased mainly on the strength of motor vehicle loans. Revolving credit (primarily credit card balances) posted a moderate gain and maintained a fairly small share of overall finance company activity. "Other" consumer loans-a diverse mix of other types of non-mortgage consumer loans-changed little on net in the late $1990 \mathrm{~s}$, and as a result, the importance to finance companies of this category of consumer loans continued to diminish.

7. A factored commercial account is an account that has been purchased by a financial institution, such as a finance company. The purchaser assumes the credit risk of nonpayment.

\section{Consumer Motor Vehicle Finance}

Financing of consumer motor vehicles by finance companies increased at an average annual rate of 12 percent between 1996 and 2000, reaching a level of $\$ 338$ billion. Most of the gain was due to growth in loans. Growth in receivables associated with leases slowed considerably from the rate of growth between 1990 and 1996. As a result of the slow growth of leases relative to the growth of loans, leases accounted for 9 percentage points less of consumer motor vehicle finance in 2000 than in 1996.

This shift away from leases partly reversed a 25 percentage point rise between 1990 and 1996 in the proportion of consumer motor vehicle finance accounted for by leases. The fourfold increase in car and truck leasing underlying the earlier gain was due largely to aggressive promotion of motor vehicle leases to households by the captive subsidiaries of motor vehicle manufacturers. These subsidiaries, which account for the bulk of finance company consumer motor vehicle lending, have traditionally used financial incentives and other innovations to increase demand for the products of their parent manufacturers. The development of the motor vehicle lease as a consumer product was one such innovation. Generally, consumers became more receptive to leasing as a result of federal tax code revisions in the mid-1980s that phased out the deductibility of consumer loan interest payments, thereby raising the cost of financing vehicle purchases relative to leasing. In addition, leasing was perceived as a way to better reach two specific portions of the consumer market. One portion was households that wanted to drive "new" vehicles at all times but were deterred from replacing their vehicles frequently by the difficulties associated

4. Consumer receivables at finance companies, by category, June 30, 1996 and 2000

\begin{tabular}{|c|c|c|c|c|c|c|c|c|}
\hline \multirow{2}{*}{ Category } & \multicolumn{2}{|c|}{$\begin{array}{c}\text { Amsunt } \\
\text { (billions of dosllits) }\end{array}$} & \multicolumn{2}{|c|}{$\begin{array}{c}\text { Growth, } 19: 2 ; \text { to } 21) 10(1 \\
\text { (per:LnL) }\end{array}$} & \multicolumn{2}{|c|}{$\begin{array}{l}\text { Share of categioly } \\
\text { (per sint) }\end{array}$} & \multicolumn{2}{|c|}{$\begin{array}{l}\text { Share of total } \\
\text { (per sunt) }\end{array}$} \\
\hline & 1996 & 2000 & Cumulative & $\begin{array}{l}\text { Average } \\
\text { annual }\end{array}$ & 1996 & 2000 & 1996 & 2000 \\
\hline Total & 303.9 & 431.8 & 42.1 & 9.2 & 100.0 & 100.0 & 100.0 & 100.0 \\
\hline Motor vehicle & 217.3 & 337.6 & 55.3 & 11.6 & 100.0 & 100.0 & 71.5 & 78.2 \\
\hline Loans & 123.0 & 220.6 & 79.3 & 15.7 & 56.6 & 65.3 & 40.5 & 51.1 \\
\hline Owned & 86.3 & 143.1 & 65.8 & 13.5 & 39.7 & 42.4 & 28.4 & 33.1 \\
\hline Securitized & 36.7 & 77.4 & 111.2 & 20.5 & 16.9 & 22.9 & 12.1 & 17.9 \\
\hline Leases ....... & 94.3 & 117.0 & 24.1 & 5.5 & 43.4 & 34.7 & 31.0 & 27.1 \\
\hline Owned & 86.7 & 109.1 & 25.8 & 5.9 & 39.9 & 32.3 & 28.5 & 25.3 \\
\hline Securitized & 7.6 & 7.9 & 4.1 & 1.0 & 3.5 & 2.3 & 2.5 & 1.8 \\
\hline Revolving . & 29.7 & 37.8 & 27.0 & 6.2 & 100.0 & 100.0 & 9.8 & 8.7 \\
\hline Owned & 29.7 & 31.1 & 4.7 & 1.2 & 100.0 & 82.4 & 9.8 & 7.2 \\
\hline Securitized & $\approx$ & 6.6 & $\ldots$ & $\ldots$ & $\approx$ & 17.6 & $*$ & 1.5 \\
\hline Other & 56.9 & 56.4 & -.8 & -.2 & 100.0 & 100.0 & 18.7 & 13.1 \\
\hline Owned & 37.8 & 38.4 & 1.7 & 4 & 66.4 & 68.1 & 12.4 & 8.9 \\
\hline Securitized & 19.1 & 18.0 & -5.7 & -1.5 & 33.6 & 31.9 & 6.3 & 4.2 \\
\hline
\end{tabular}


with reselling them. The other portion was households that were unable to make regular payments on vehicle loans but could afford the smaller payments typically associated with leasing.

According to industry analysts, the shift away from leasing in recent years has occurred because consumer auto leasing has turned out to be less profitable for finance companies than anticipated. A softer-thanexpected used car market depressed the actual value of many vehicles at the end of the lease period relative to the "residual value" stated in the leasing agreement. The losses associated with these weak used car prices were exacerbated by larger-thanexpected turn-in ratios (the fraction of households not exercising their option to purchase the leased vehicle), which left finance companies with large numbers of previously leased vehicles to sell. Both the weakness in used car prices and the high turn-in ratios appear to be at least partly related to the relatively rapid rate of model development and the small price increases that characterized the new car market in the second half of the 1990s.

One pattern in consumer motor vehicle finance that has not changed since the early 1990s is the trend toward securitization. The value of securitized motor vehicle loans at finance companies rose at an average annual rate of 21 percent between 1996 and 2000. In 2000, securitized loans and leases represented just over 25 percent of finance company consumer motor vehicle receivables, up from roughly 20 percent in 1996 and about 15 percent in 1990. The captive finance companies, which account for a sizable portion of outstanding securitized motor vehicle receivables, continued to have reliable access to the securitization market through 2000 because they dealt mainly with higher quality loans.

\section{Revolving Credit}

Finance company revolving credit-mostly credit card receivables - rose from $\$ 30$ billion to $\$ 38$ billion between 1996 and 2000, or about 6 percent a year on average. ${ }^{3}$ Most of the increase was due to an increase in loans in securitized pools. Investor demand for this type of asset remained strong through the late $1990 \mathrm{~s}$, as the economic expansion resulted in continued gains in credit quality.

8. The 1996 data for revolving and "other" consumer receivables in table 4 are lower than those cited in James D. August, Michael R. Grupe, Charles Luckett, and Samuel M. Slowinski, "Survey of Finance Companies, 1996," Federal Reserve Bulletin, vol. 83 (July 1997), pp. 543-56. After publication of that article, the receivables of several commercial bank subsidiaries that had been included in the totals reported by some finance companies were removed from the various series.
The pace of growth of finance company revolving credit (owned or securitized) was similar to that for such loans from all sources. As a result, finance companies continued to account for a fairly small share of the consumer revolving credit market, about 6 percent of total revolving credit outstanding.

\section{Other Consumer Receivables}

Finance company consumer receivables aside from the motor vehicle and revolving credit categories were little changed between 1996 and 2000. The largest component of the "other" category most likely is personal cash loans. ${ }^{7}$ Another important component is sales finance contracts-loans typically originated by retail stores to finance the purchase of such items as furniture or appliances and often sold to finance companies. A third component is mobile home loans (these loans constitute the collateral behind most of the securitized loans in the "other" category).

The lackluster performance of finance companies in the "other" category between 1996 and 2000 continued a trend seen in the early $1990 \mathrm{~s}$, when growth in the category also lagged growth in the other categories of consumer receivables, albeit to a lesser extent. The declining importance of "other" loans is probably related to the growing role of credit cards. In particular, revolving credit has become more available to consumers who formerly had to rely on non-revolving finance company credit: During the 1990 s, banks on balance moved toward riskier households in their marketing of credit cards, and several large finance companies established credit card operations.

\section{Real Estate Receivables}

Real estate lending by finance companies increased at an average annual rate of close to 16 percent between 1996 and 2000 (table 5). Despite this impressive pace of expansion, finance companies continued to account for a very small share of total residential and commercial mortgage lending. In mid-2000, outstanding

9. Surveyed companies were first asked about loans for the purchase of motor vehicles, revolving lines of credit, and loans secured by real estate. Then they were asked about loans and other types of credit extended to households that did not fall into those three categories; these remaining receivables make up the "other" category. Companies were not asked to report any detail for "other" consumer receivables; see appendix B for more information about the category. 
5. Real estate receivables at finance companies, by category, June 30, 1996 and 2000

\begin{tabular}{|c|c|c|c|c|c|c|c|c|}
\hline \multirow{2}{*}{ Category } & \multicolumn{2}{|c|}{$\begin{array}{c}\text { Am sumt } \\
\text { (billions of dollars) }\end{array}$} & \multicolumn{2}{|c|}{$\begin{array}{c}\text { Growth, } 1936 \text { wi } 20001 \\
\text { (per:ent) }\end{array}$} & \multicolumn{2}{|c|}{$\begin{array}{c}\text { Share of entisgery } \\
\text { (per:ent) }\end{array}$} & \multicolumn{2}{|c|}{$\begin{array}{l}\text { Share of totiil } \\
\text { (persent) }\end{array}$} \\
\hline & 1996 & 2000 & Cumulative & $\begin{array}{l}\text { Average } \\
\text { annual }\end{array}$ & 1996 & 2000 & 1996 & 2000 \\
\hline Total & 103.8 & 185.3 & 78.5 & 15.6 & 100.0 & 100.0 & 100.0 & 100.0 \\
\hline $\begin{array}{l}\text { One- to four-family } \\
\text { Owned } \ldots \ldots . . . \\
\text { Securitized }\end{array}$ & $\begin{array}{l}70.7 \\
47.3 \\
23.4\end{array}$ & $\begin{array}{r}146.8 \\
119.4 \\
27.4\end{array}$ & $\begin{array}{r}107.6 \\
152.6 \\
16.7\end{array}$ & $\begin{array}{r}20.0 \\
26.1 \\
3.9\end{array}$ & $\begin{array}{r}100.0 \\
66.8 \\
33.2\end{array}$ & $\begin{array}{r}100.0 \\
81.4 \\
18.6\end{array}$ & $\begin{array}{l}68.1 \\
45.5 \\
22.6\end{array}$ & $\begin{array}{l}79.2 \\
64.4 \\
14.8\end{array}$ \\
\hline $\begin{array}{c}\text { Commercial } \\
\text { Owned } \\
\text { Securitized }\end{array}$ & $\begin{array}{c}33.1 \\
33.1 \\
\approx\end{array}$ & $\begin{array}{r}38.5 \\
38.4 \\
.2\end{array}$ & $\begin{array}{l}16.4 \\
15.9 \\
\ldots\end{array}$ & $\begin{array}{r}3.9 \\
3.8 \\
-\end{array}$ & $\begin{array}{c}100.0 \\
100.0 \\
\approx\end{array}$ & $\begin{array}{r}100.0 \\
99.5 \\
.5\end{array}$ & $\begin{array}{c}31.9 \\
31.9 \\
*\end{array}$ & $\begin{array}{r}20.8 \\
20.7 \\
.1\end{array}$ \\
\hline
\end{tabular}

finance company loans totaled $\$ 185$ billion, less than 3 percent of the overall mortgage market. ${ }^{10}$

Loans to individual homeowners secured by oneto four-family homes are by far the largest component of finance company real estate receivables, and they accounted for the bulk of the growth between 1996 and 2000. Such loans rose at a vigorous average annual rate of 20 percent over the period, reaching $\$ 147$ billion. Most of the additional lending was retained on the balance sheets of finance companies; securitized loans in this category rose much less rapidly than total loans. Commercial mortgages, including mortgages on farm and multifamily properties, expanded an average of 4 percent a year between 1996 and 2000. As of mid-2000, they represented just under 21 percent of real estate lending by finance companies, down from a 32 percent share in 1996.

Almost all finance company real estate loans to individuals are home equity loans rather than loans to purchase homes. " As a result, finance companies represent a larger share of the market for home equity loans than they do of the broader mortgage market. Total home equity lending is estimated to have been a little more than $\$ 500$ billion in mid-2000. The largest source of this credit was commercial banks, which held more than one-third of the total. Finance companies are estimated to have held about 20 percent of the total, up from roughly 15 percent in mid-1996.

Data on finance company real estate loans to individuals before 1996 are not available. ${ }^{12}$ However, the

10. The figures for finance company real estate receivables (indeed, all figures for finance companies) do not include data for mortgage banking companies. These specialized home mortgage lenders, which act primarily as mortgage originators and finance their lending activities almost exclusively through securitization, are not covered by the finance company survey

11. Although the survey does not ask for details about real estate loans, this is generally believed to be the case.

12. Before the 1996 survey, finance companies were not asked to disaggregate their real estate receivables into their home mortgage and commercial components. sharp upward trend in the late 1990s mirrors a rapid growth of total home equity lending that began in the middle of the decade. The increase in home equity lending was probably due at least partly to ongoing increases in households' use of this type of credit to consolidate their debt. The presence of collateral for these loans generally holds the interest rates below rates for most credit cards. Further, the repayment period on a home equity loan is typically longer than the implicit repayment period for credit card borrowing. As a result, borrowers who use home equity loans to pay down their credit card balances can substantially reduce their monthly payments. Another advantage of home equity loans over credit card borrowing is that interest paid on home equity loans is deductible for taxpayers who itemize such expenses.

\section{FINANCE COMPANY FUNDING SOURCES}

Finance company funding sources remained relatively stable between 1996 and 2000 . The companies continued to operate from a narrow equity base. Capital, surplus, and undivided profits as a proportion of total assets was unchanged at about 11 percent (table 6). The most important source of funds, accounting for more than one-third of finance company funding, remained corporate bonds, the primary component of "debt not elsewhere classified." Finance companies' reliance on commercial paper continued to decline, falling 3 percentage points, to 18 percent. Bank borrowing and "other," unspecified, sources continued to fund about 2 percent and 20 percent of assets, respectively. Debt due to a parent company rose at an average annual rate of 14 percent between 1996 and 2000, reaching 8 percent of total funding. As mentioned earlier, finance companies increased their securitization activity rapidly between 1990 and 1996; however, the growth of securitized pools between 1996 and 2000 about equaled the 
6. Sources of finance company funding, June 30, 1996 and 2000

\begin{tabular}{|c|c|c|c|c|c|c|}
\hline \multirow{2}{*}{ Source } & \multicolumn{2}{|c|}{$\begin{array}{l}\text { Outstanding } \\
\text { (billions cf dollars) }\end{array}$} & \multicolumn{2}{|c|}{$\begin{array}{l}\text { Growth, } 1936 \text { is } 2 \text { loili } \\
\text { (per:ent) }\end{array}$} & \multicolumn{2}{|c|}{$\begin{array}{l}\text { Share of totiil } \\
\text { (per:ent) }\end{array}$} \\
\hline & 1996 & 2000 & Cumulative & Average annual & 1996 & 2000 \\
\hline Liabilities & 725.7 & $1,113.4$ & 53.4 & 11.3 & 89.0 & 88.4 \\
\hline Bank loans & 17.7 & 32.8 & 85.7 & 16.7 & 2.2 & 2.6 \\
\hline Commercial paper & 169.6 & 224.3 & 32.3 & 7.2 & 20.8 & 17.8 \\
\hline Debt due to parent & 56.3 & 95.1 & 68.9 & 14.0 & 6.9 & 7.6 \\
\hline Debt not elsewhere classified & 3190 & 483.7 & 51.6 & 11.0 & 39.1 & 38.4 \\
\hline Other $\ldots \ldots \ldots \ldots \ldots \ldots$ & 163.2 & 277.5 & 70.1 & 14.2 & 20.0 & 22.0 \\
\hline Capital, surplus, and undivided profits & 89.7 & 145.7 & 62.4 & 12.9 & 11.0 & 11.6 \\
\hline Total & 815.4 & $1,259.0$ & 54.4 & 11.5 & 100.0 & 100.0 \\
\hline Мем. & & & & & & \\
\hline Securitized receivables & 122.4 & 198.1 & 61.9 & 12.8 & 13.1 & 13.6 \\
\hline Total managed assets & 937.8 & $1,457.1$ & 55.4 & 11.6 & 100.0 & 100.0 \\
\hline
\end{tabular}

growth of other forms of financing, and securitized assets remained at about 13 percent of total managed assets in $2000 .^{13}$

\section{DEVELOPMENTS SINCE THE JUNE 2000 BENCHMARK SURVEY}

Information on the pattern of finance company activity since the June 2000 benchmark survey is available from the Federal Reserve System's monthly survey of finance companies. ${ }^{14}$ Over the fifteen months between the end of June 2000 and the end of September 2001, finance company receivables, adjusted to remove normal seasonal patterns, grew at an average annual rate of close to 9 percent. This pace was slightly less rapid than the trend over the preceding four years. However, the gains were not spread evenly over the post-benchmark period. In particular, the general weakening of macroeconomic activity since late 2000 showed through to overall finance company lending, and the rate of growth of total receivables trended down steadily (chart 2).

The slowing of overall finance company lending was due primarily to a sharp deceleration in finance company business receivables that began in the second half of 2000 . The rate of growth of real estate and consumer receivables moved down much less dramatically. In general, the demand for both home equity loans and consumer loans most likely was buoyed by some households' efforts to sustain the rate of growth of their consumption in the face of what they perceived as a temporary slowing of

13. Total managed assets equal the sum of total assets and securitized receivables.

14. Among other differences, the sample for the monthly survey is smaller than that for the benchmark survey; thus, the figures are subject to greater measurement and sampling error. income and employment growth. Some categoryspecific factors probably also came into play. Home equity lending likely was boosted by the combination of low mortgage rates and relatively rapid appreciation of house prices. Generous incentives offered by the captive finance company subsidiaries of motor vehicle manufacturers helped maintain solid growth in consumer motor vehicle receivables. Finally, consumer receivables were boosted in late 2000 when a major finance company absorbed the securitized receivables of one of its non-finance company affiliates. ${ }^{15}$

15. This transfer of assets explains some, but not all, of the increase in the rate of growth of finance company consumer receivables in late 2000 . Without the transfer, the twelve-month change in the consumer component would have been a little more than 1 percentage point lower beginning in the fourth quarter of 2000 , and the twelve-month change in total receivables would have been roughly $\because 2$ percentage point lower. Note that estimates of consumer lending from all sources were unaffected by this event because the increase in securitized loans held by finance companies was offset by a decline in securitized loans held elsewhere.

2. Growth of finance company receivables, June 2000-September 2001

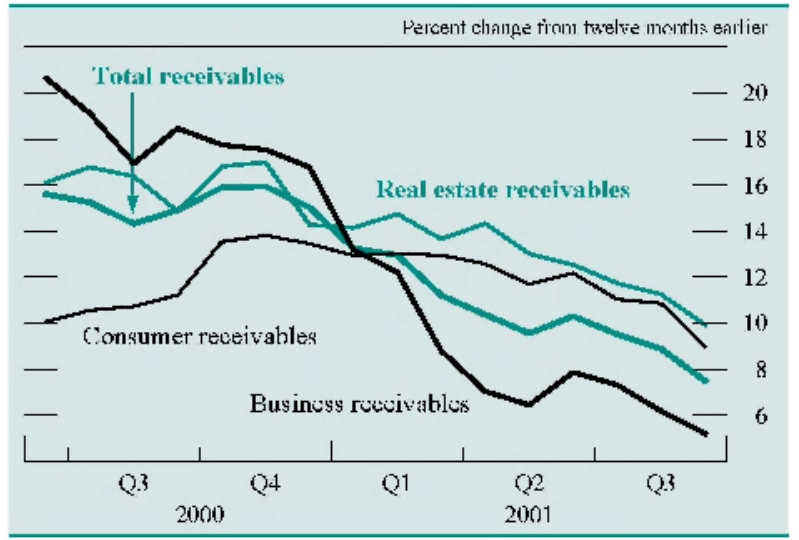




\section{APPENDIX A: SAMPLING PROCEDURES}

As a first step in establishing a population for the 2000 benchmark survey, pre-survey questionnaires were mailed to 2,589 companies that were identified from the mailing list for the 1996 survey and from other sources. Data were collected on the size of the company, its primary type of activity or specialty, and the classification of its parent, if any. Companies that responded to the questionnaire with information showing that they had gone out of business, had been sold to another firm, were not a finance company, or were a subsidiary of another finance company were excluded from the population (table A.1).

Follow-up investigations of companies that did not return the pre-survey questionnaire or whose questionnaires were returned by the Postal Service as undeliverable ("postal returns") were conducted to estimate the number of additional companies that belonged in the population. Investigations of a stratified random sample of 240 companies drawn from the 860 nonresponding companies yielded 78 eligible companies. Projecting this result on the basis of size and specialty class added 280 companies to the population. Similarly, investigations of a stratified random sample of 50 companies drawn from the 573 postal returns yielded 5 eligible companies, adding 57 companies to the population. Combining these estimates with the usable responses to the pre-survey questionnaire, the population of finance companies on June 30, 2000, was initially estimated at 1,012.

The sample for the 2000 benchmark survey consisted of two groups: the 58 finance companies surveyed monthly for the Domestic Finance Company Report (FR 2248) and a stratified random sample of 542 additional companies from the sampling frame. All 58 monthly reporters responded. A total of 121 of the 542 sampled companies provided usable responses. The responses of another 28 of the 542 sampled companies indicated that they no longer fit the definition of "finance company" or had not fit the

\section{A.1. Responses to pre-survey questionnaire}

\begin{tabular}{|c|c|c|}
\hline Disposition & Number & $\begin{array}{l}\text { Percent of } \\
\text { total mailed }\end{array}$ \\
\hline Total mailed & 2,589 & 100.0 \\
\hline Not returned & 860 & 33.2 \\
\hline Returned .. & 1,729 & 66.8 \\
\hline Usable & 675 & 26.1 \\
\hline Not usable & 1,054 & 40.7 \\
\hline Postal return & 573 & 22.1 \\
\hline Not a finance company & 164 & 6.3 \\
\hline Out of business $\ldots \ldots \ldots \ldots$ & 181 & 7.0 \\
\hline Finance company subsidiary & 90 & 3.5 \\
\hline Bank subsidiary ............ & 26 & 1.0 \\
\hline Other & 20 & 8 \\
\hline
\end{tabular}

definition at the time of the questionnaire. These 28 companies were removed from the population, leaving a final estimated population of 984 companies.

Estimates of the assets and liabilities of the finance company population were produced using the stratified mean expansion estimator, where the strata were based on both the size and the lending specialty of the company. The estimator was defined as

$$
Y=\Sigma Y(h)=\sum \frac{N(h) * y(h)}{n(h)}
$$

where

$$
\begin{aligned}
Y= & \text { estimated national total } \\
Y(h)= & \text { estimated aggregate total for stratum } h \\
N(h)= & \text { total number of companies in stratum } h \\
y(h)= & \text { sample aggregate total for companies in } \\
& \text { stratum } h \\
n(h)= & \text { number of sample companies in stratum } h
\end{aligned}
$$

APPENDIX B: DEFINITIONS OF BALANCE SHEET. ITEMS AND ADDITIONAL BALANCE SHEET DATA

For purposes of this survey, a finance company was defined as a company (excluding commercial banks, credit unions, savings and loan associations, cooperative banks, and savings banks) in which the largest portion of the company's assets was in one or more of the following kinds of receivables:

- Sales finance receivables. Installment paper arising from retail sales of passenger cars and mobile homes, other consumer goods, such as general merchandise, apparel, furniture, and household appliances, or from outlays for home-improvement loans not secured by real estate.

- Personal cash loans to individuals and families. Unsecured cash loans (including loans to pay for insurance policies) or cash loans secured by insurance policies, autos already paid for, or other collateral.

- Short- and intermediate-term business receivables (including leases). Loans on commercial accounts receivable; inventory loans; factoring; lease financing; retail installment sales (or purchases) of commercial, industrial, and farm equipment and commercial vehicles; and wholesale financing of consumer and business goods. 
- Junion liens on real estate. Loans, whatever the purpose, secured by junior liens (for example, equity loans or second mortgages) on real estate as evidenced by junior mortgages, deeds of trust, land contracts, or other instruments.

\section{Asset Items}

Receivables include direct loans and loans and paper purchased from manufacturers and retailers before deduction of capitalized unearned income and reserves for losses.

\section{Consumer Receivables}

A. Motor Vehicle Financing. Credit arising from retail sales of passenger cars and other vehicles such as vans and pickup trucks to consumers. It excludes fleet sales, personal cash loans secured by automobiles already paid for, loans to finance the purchase of commercial vehicles and farm equipment, and lease financing.

B. Revolving Credit. Retail credit that is extended on a credit-line basis and that arises from the sale of consumer goods other than passenger cars and other vehicles. A single contract governs multiple use of the account, and purchases may be made with a credit card. Generally, credit extensions can be made at the consumer's discretion, provided that they do not cause the outstanding balance of the account to exceed a prearranged credit limit.

C. Other Consumer Receivables. All credit arising from retail sales of non-motor vehicle consumer goods that is not extended under a revolving credit line. It includes financing of general merchandise, apparel, furniture, and household appliances; campers, trailers, mobile homes, motorcycles, airplanes, helicopters, and boats purchased for personal use; loans for automobile repair; credit to finance alterations or improvements in existing residential properties occupied by the borrower; secured and unsecured loans made directly to the borrower for household, family, or other personal expenses; and unsecured loans to purchase auto insurance policies as well as loans secured by insurance policies, automobiles already paid for, and other collateral. It excludes loans for business purposes, rediscounted loans, loans secured by real estate, and wholesale and lease financing.

\section{Loans Secured by Real Estate}

A. One- to Four-Family. Credit arising from revolving or permanent loans secured by real estate as evidenced by mortgages (FHA, FmHA, VA, or conventional) or other liens (first or junior) on nonfarm property containing one to four dwelling units (including vacation homes) or more than four dwelling units if each is separated from other units by dividing walls that extend from ground to roof (row houses, townhouses, or the like); mobile homes when state laws define the purchase or holding of a mobile home as the purchase or holding of real property and where the loan to purchase the mobile home is secured by that mobile home as evidenced by a mortgage or other instrument on real property; individual condominium dwelling units and loans secured by an interest in individual cooperative units, even if in a building with five or more dwelling units; vacant lots in established single-family residential sections or in areas set aside primarily for one- to four-family homes; and housekeeping dwellings with commercial units combined where use is primarily residential and where only one- to four-family dwelling units are involved.

B. Multifamily. Credit arising from permanent nonfarm residential loans secured by real estate as evidenced by mortgages (FHA or conventional) or other liens on nonfarm properties with five or more dwelling units in structures (including apartment buildings and apartment hotels) used primarily to accommodate households on a more or less permanent basis; housekeeping dwellings of five or more units with commercial units combined where use is primarily residential; cooperative-type apartment buildings containing five or more dwelling units; and vacant lots in established multifamily residential sections or in areas set aside primarily for multifamily residential properties.

C. Commercial and Farm. Credit arising from loans secured by real estate as evidenced by mortgages or other liens on business and industrial properties, hotels, motels, churches, hospitals, educational and charitable institutions, dormitories, clubs, lodges, association buildings, care facilities for aged persons and orphans, golf courses, recreational facilities, and similar properties. It includes all other nonresidential loans secured by real estate as evidenced by mortgages or other liens. It also includes credit arising 
from loans secured by farmland and improvements thereon as evidenced by mortgages or other liens. Farmland includes all land known to be used or usable for agricultural purposes, such as crop and livestock production, and grazing or pasture land, whether tillable or not and whether wooded or not.

\section{Business Receivables}

A. Motor Vehicle Financing. Consists of retail credits and wholesale credits.

(1) Retail (commercial vehicles). Credit arising from retail sales of commercial land vehicles to business. It includes trucks, buses, taxicabs, truck trailers, and other on-the-road vehicles for which motor vehicle licensing is required. It also includes fleet sales of passenger cars, but excludes lease financing and paper on business, industrial, or farm equipment.

(2) Wholesale. Credit arising from transactions between manufacturers and dealers or other floorplan loans secured by passenger cars and commercial land vehicles. It excludes paper secured by mobile homes, passenger car trailers, boats, airplanes, helicopters, and business, industrial, and farm equipment.

B. Business, Industrial, and Farm Equipment. Consists of retail and wholesale credits and capital and leveraged leases.

(1) Retail and wholesale financing. Credit arising from the retail sale to business of (or for the purchase of) business, industrial, and farm equipment. It includes all off-the-road equipment for which motor vehicle licensing is not required as well as airplanes, helicopters, and boats purchased for business use. Loans may be secured by chattel mortgages or conditional sales contracts (purchased money security agreements) on the machinery or equipment. It excludes loans to purchase commercial land vehicles for which motor vehicle licensing is required and loans secured by real estate. It also excludes lease financing. Wholesale financing is credit arising from transactions between manufacturers and dealers or other floor-plan loans secured by business, industrial, and farm equipment. It includes all off-the-road equipment for which motor vehicle licensing is not required, such as airplanes, helicopters, and boats.

(2) Capital and leveraged leases. Lease receivables arising from the leasing of business, industrial, and farm equipment. It includes lease financing of all off-the-road equipment for which motor vehicle licensing is not required and lease financing of airplanes, helicopters, and boats leased for business use. It excludes lease financing of airplanes, helicopters, and boats leased for personal or family use (included in asset item 3.C), and excludes operating leases as defined by Financial Accounting Standards Board Statement of Financial Accounting Standards 13 (SFAS 13).

C. Other Business Receivables (Excluding Operating Leases). All other wholesale financing not reported in asset items 3.A.2 and 3.B.1 above, including floor-plan transactions between manufacturers and dealers for items such as mobile homes, campers, and travel trailers. Includes all other business capital and leveraged lease receivables not reported in asset items 3.B. 2 above and not reported in asset items 4.A.2, below, including credit arising from the leasing of mobile homes, campers, and travel trailers. Excludes operating leases as defined by SFAS 13 that are included in asset items 4.B and 5 below. Includes business credit with original maturities of up to five years, including loans secured by commercial accounts receivable less the balances withheld for customers pending collection of receivables; commercial accounts receivable purchased from factored clients less any amount due and payable to factored clients; and secured and unsecured advances of funds to factored clients. It includes dealer loans, capital loans, small loans used primarily for business or farm purposes, multicollateral loans, rediscounted receivables of other finance companies less balances withheld, and all other business loans not elsewhere classified. It excludes loans secured by real estate (unless included as part of a multicollateral loan), which are included in asset items 2 .

\section{Motor Vehicle Leases}

Lease receivables arising from leasing of passenger cars and commercial land vehicles, but excluding leasing of mobile homes, campers, motor trailers, boats, airplanes, helicopters, and business, industrial, and farm equipment.

A. Capital and Leveraged Leases. Consists of consumer and business leases.

(1) Consumer. Refer to credit on types of receivables covered by asset items 1.A above. 
(2) Business. Refer to credit on types of receivables covered by asset items 3.A.1 above.

B. Operating Leases (as defined by SFAS 13). Consists of consumer and business leases.

(1) Consumer. Refer to credit on types of receivables covered by asset items 1.A above.

(2) Business. Refer to credit on types of receivables covered by asset items 3.A.1 above.

\section{Non-Motor Vehicle Operating Leases}

For business, industrial, and farm equipment, refer to credit on types of receivables covered by asset items 3.B.1 above. For all other equipment, refer to credit on types of receivables covered by asset items 1.C and 3.C above. It includes all operating leases as defined by SFAS 13 that are excluded from the asset items above.

A. Consumer. Refer to credit on types of receivables covered by asset items 1.C above.

B. Business. Refer to credit on types of receivables covered by asset items 3.B.1 and 3.C above.

\section{All Other Assets and Accounts and Notes Receivable}

All assets not already included above, including consolidated companies' investments in nonconsolidated foreign and domestic subsidiaries and affiliates. Nonconsolidated subsidiary and affiliate company claims on consolidated companies (except debt due to parent) are netted against the consolidated companies' investment. It excludes operating leases reported as asset items 4.B and 5 above and excludes overdrafts.

\section{Reserves}

A. Reserves for Unearned Income. Includes unearned discounts and service charges on the above receivables.

B. Reserves for Losses. Allowances for bad debts, unallocated charge-offs, and any other valuation allowances except the amount of unearned income applicable to the receivables included above.

\section{Total Assets, Net}

Sum of asset items 1.A through 6 minus asset items 7.A and 7.B.

\section{Securitized Asset Items}

Securitized assets include receivables that have been packaged and sold by the reporting finance company to a trustee or other third party who uses the receivables package as collateral for an asset-backed security that is sold to investors. These assets are no longer on the balance sheet of the reporting finance company and thus are not included in the asset items. Securitized assets consist of the total amount outstanding, including all receivables securitized in the current month and in prior months. They include assets such as leases that were never on the company books, but whose securitizations may be counted as a managed asset, and exclude the amounts of outright asset sales that have not been packaged to collateralize an asset-backed security. Securitized assets are reported using the same definitions used for their unsecuritized counterparts in asset items 1 through 5 above.

\section{Liabilities and Capital Items}

\section{Bank Loans}

Short- and long-term loans and notes payable to banks. Includes overdrafts but excludes commercial paper and bank portions of participation loans.

\section{Commercial Paper}

Promissory notes of large denominations sold directly or through dealers to investors and issued for not longer than 270 days. It includes short-term or demand "master" notes and paper backed by letters of credit or other guarantees, but excludes nonnegotiable promissory notes held by officers of the firm, their families, and other individuals (which are included in liabilities and capital item 4).

\section{Debt Due to Parent}

For a company that is the subsidiary of another company (which is not a finance company), it 
includes all short- and long-term indebtedness owed to the parent company, but excludes the parent company's equity (which is included in liabilities and capital item 6).

\section{Debt Not Elsewhere Classified}

All other short- and long-term loans, notes, certificates, negotiable paper, or other indebtedness not elsewhere classified. It excludes bank debt already included in liabilities and capital items 1 and 3.

\section{All Other Liabilities}

All liabilities not already reported above or netted against assets. It includes dealer reserves, all tax accruals, short-term certificates of thrift or investment, deposit liabilities (other than those not with- drawable during term of loan), and all other liabilities. It excludes liabilities of consolidated companies to nonconsolidated subsidiaries of affiliated companies, which are netted against assets in asset items 6 or shown in liabilities and capital items 3. It also excludes borrower repayment deposits accumulated but not credited against indebtedness until repayment is made in full, which are netted against appropriate receivables under asset items above.

\section{Capital, Surplus, and Undivided Profits}

All common and preferred stock and other capital or surplus accounts, including undivided profits.

7. Total Liabilities and Capital

Sum of liabilities and capital items 1 through 6 .

Table B.1 appears on the following page. 
B.1. Assets and liabilities outstanding at finance companies, by size of company, June 30,2000 Millions of dollars

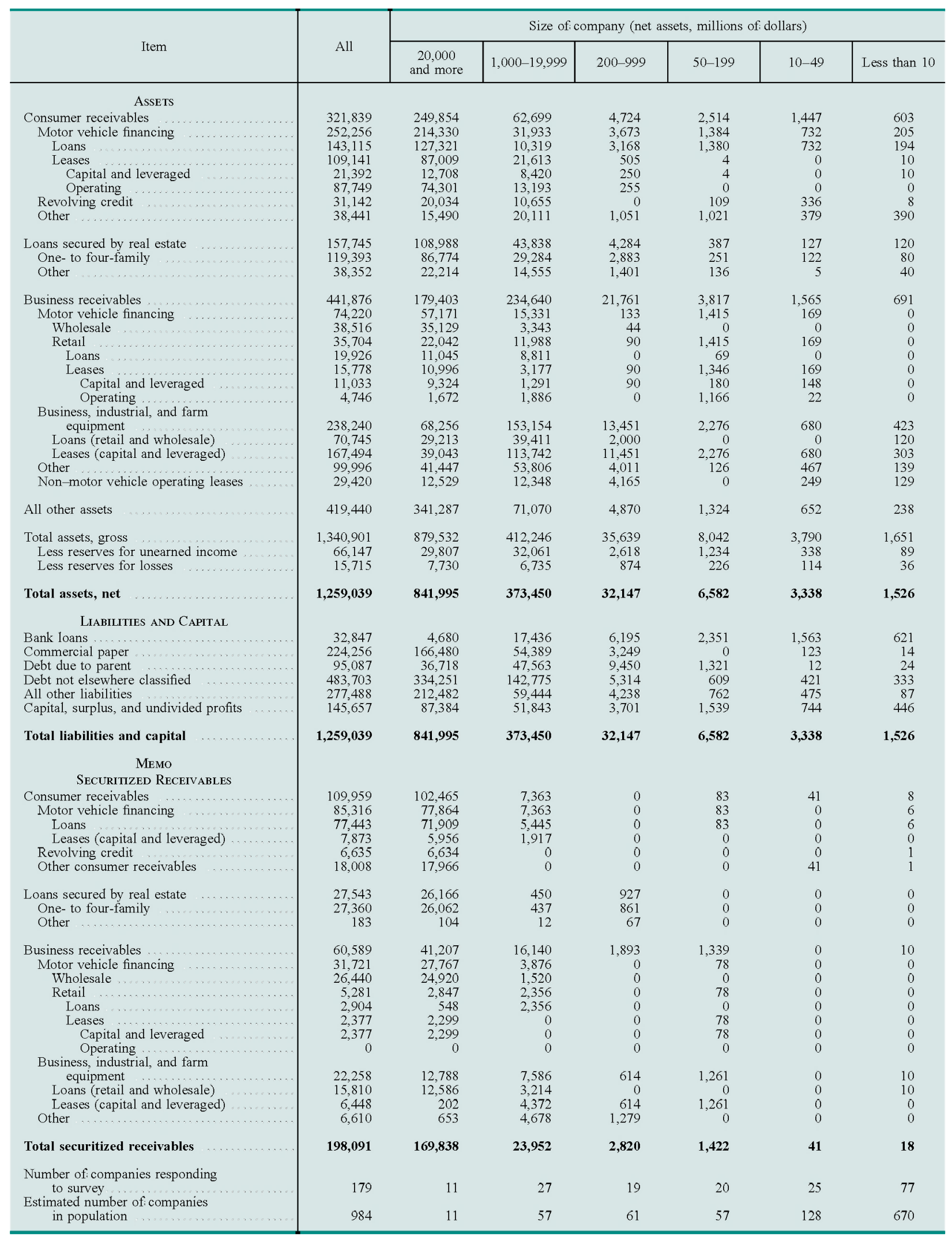

